\title{
Stability of anthocyanin in spinach vine (Basella rubra) fruits
}

\author{
Eliana Ferreira Ozela ${ }^{1}$, Paulo César Stringheta ${ }^{2}$, and Milton Cano Chauca ${ }^{3}$ \\ 'Department of Pharmacy, Federal University of Pará, Campus of Guamá, 66075-900, Belém, PA, Brazil. \\ ${ }^{2}$ Department of Food Technology, Federal University of Viçosa, UFV. 36571-000, Viçosa, MG, Brazil. \\ ${ }^{3}$ Department of Agricultural Sciences, Montes Claros Stat University- UNIMONTES. 39440-000, \\ Janauba, MG, Brazil.
}

\begin{abstract}
E. Ferreira Ozela, P. César Stringheta, and M. Cano Chauca. 2007. Stability of anthocyanin in spinach vine (Basella rubra) fruits. Cien. Inv. Agr 34(2):115-120. The stability of anthocyanin in the extract of spinach vine fruit (Basella rubra L.) was studied in relation to degradative factors such as light, temperature and $\mathrm{pH}$ acting alone or in combination. In this work, the possible use of spinach vine fruit as a source of natural pigments for use in food coloring was evaluated. Extraction of the pigment was carried out with $99.9 \%$ methanol at $\mathrm{pH}$ 2.0. The stability of the anthocyanin extract was estimated. From these values, reaction velocity constants $(\mathrm{k})$ as well as the half-life time $\left(\mathrm{t}_{1 / 2}\right)$ were calculated at $\mathrm{pH} 4.0,5.0$, and 6.0 in the presence and absence of light both at 40 and $60^{\circ} \mathrm{C}$. Results indicate that, independent of $\mathrm{pH}$ values, spinach vine extract suffered an interference of light in its anthocyanin degradation kinetics with the mean $\mathrm{t}_{1 / 2}$ being greater in samples place in darkness $(654.5 \pm 66.6 \mathrm{~h})$ compared to exposed to light $(280 \pm 60.62 \mathrm{~h})$. In the presence of light, degradation of the anthocyanin pigment increased with increased temperature and had an average half life time of $280 \pm 60.62$ $\mathrm{h}, 6.88 \pm 0.76 \mathrm{~h}$ and $2.42 \pm 0.31 \mathrm{~h}$ at room temperature $\left(25 \pm 1^{\circ} \mathrm{C}\right), 40$ and $60^{\circ} \mathrm{C}$, respectively. Spinach vine extract was more stable at $\mathrm{pH} 5.0$ and 6.0 than at $\mathrm{pH} 4.0$ both in the presence and absence of light. This characteristic differs from other anthocyanins. This property could facilitate its application as a natural food colorant.
\end{abstract}

Key words: Anthocyanin, bertalha, coloring, food color, spinach vine.

\section{Introduction}

The practice of coloring food is very old and the natural pigments found in spices and seasonings were the first to be studied for such purposes. This was followed by the emergence of inorganic pigments which proved to be very harmful to human health. According to Carvalho (1992), there is a need for replacement of the artificial dyes used in the food industry with natural dyes because of the general toxicity presented by artificial dyes, making them undesirable for human consumption. This fact led researchers to investigate the whole biosphere of raw material for the production of natural dyes with suitable properties for use in food

Received 29 September 2006. Accepted 13 March 2007.

${ }^{1}$ Corresponding author: miltonc $9($ hotmail.com industry. Furthermore, some natural pigments have functional significance. Recent studies using purified anthocyanins or anthocyaninrich extracts in in vitro experimental systems have confirmed the coloring potential of these pigments. Demonstrable benefits include protection against liver injuries, significant reduction of blood pressure, improvement of eyesight, strong anti-inflammatory and antimicrobial activities, inhibition of mutations caused by mutagens from cooked food and suppression of human cancer cell proliferation. Along with other phenolic compounds, these extracts are potent scavengers of free radicals, although they can also behave as prooxidants. Because of their diverse physiological activities, the consumption of anthocyanins by human beings may play a significant role in preventing cancer, diabetes and cardiovascular and neurological diseases. 
According to Delgado-Vargas et al. (2000), the commercial production of natural pigments has been retarded due to shortage of significant quantities of highly pigmented fresh plant tissues and lack of simple and efficient methods of extraction and purification of these products from plants. However, the replacement of synthetic dyes with natural pigments presents problems including lack of pigment sources that can be used commercially, low stability and lack of simple and efficient methods of extraction and purification of these products (Ozela, 2004).

Spinach vine ("barthella") is a common name for some species of the Basellaceae family. The most common species of this family are: Basella rubra L. and B. alba L. Spinach vine is a vegetable, is easy to produce and commonly consumed, mainly in the Southeast of Brazil. Its leaves are known for being rich in $\beta$-carotene and vitamin $\mathrm{A}$, and fruits are purplish-red and fleshy. Their pigments are soluble in water and offer great tinctural power, which makes them a potential source of natural dye.

Anthocyanins are glycosilates from anthocyanidins, the nucleus of which is the structure of a 4'-hidroxiflavilum ion. All anthocyanins are composed of two or three parts: the basic structure, which is aglycone (anthocyanidin), sugar and frequently an acyl group (Francis, 1992). The most common order of sugar frequency is: glucose, rhamnose, xylose, galactose, arabinose and fructose. However, in some cases anthocyanidins can be glycosylated. The glicosylation can occur in positions 3,5 or 7 , as the most common ones are linked to hydroxyls in positions 3 and 5 and the least common to hydroxyl in 7 (Lee and Hong, 1992). Anthocyanins are responsible for the blue, red, violet and purple coloration in most species of plant kingdom (Hidrazina, 1982). Anthocyanins, like other natural pigments, present low stability. Degradation can occur during extraction, purification, processing and storage of the pigments. Factors that affect the stability of anthocyanins are: chemical structure of the pigments, $\mathrm{pH}$, temperature, and solvent type. One of the main characteristics of anthocyanins is the change in solution coloration in response to the $\mathrm{pH}$ of the environment. The color and stability of an anthocyanin in solution is highly dependent on $\mathrm{pH}$. Anthocyanins are most stable and most highly colored at low $\mathrm{pH}$ values and gradually lose color as the $\mathrm{pH}$ increases, becoming almost colorless between $\mathrm{pH} 4.0$ and 5.0. This color loss is reversible and the red hue will return upon acidification. This characteristic limits the application of anthocyanins as a food colorant to products that have a low pH values (Ramos et al., 2000). Anthocyanins predominantly exist in their noncolored forms in neutral to slightly acidic $\mathrm{pH}$ (Mazza, 1995). According to Brouillard (1982), anthocyanins are more stable in acidic than in neutral or alkaline solutions.

The stability of anthocyanins and the rate of degradation are notably influenced by temperature. Thermal stability of anthocyanins varies with temperature and $\mathrm{pH}$. The presence of oxygen and interactions with other components, like sugars and ascorbic acid also affect anthocyanin stability. The main cause of pigment color loss seems to be related to anthocyanin hydrolysis due to the observed proportionality between the speed of red color disappearance from anthocyanins and the velocity of free sugar formation. Heat causes anthocyanins, which are found at $\mathrm{pH} 2.0$ to 4.0, to undergo hydrolysis at glycoside linkages to produce chalcone and, later, alpha-diketones (Adams, 1973).

This work was carried out with the objective of studying the stability of pigments present in spinach vine fruits (B. rubra) in the presence and absence of light and at different pHs and temperatures as well as determining their reaction velocity constant $(\mathrm{k})$ and half-life time $\left(\mathrm{t}_{1 / 2}\right)$.

\section{Methods and materials}

\section{Raw material}

The raw material used in these trials was grown at Filogonio Peixoto Experimental Station, CEPLAC, located at Linhares municipality, Espírito Santo, Brazil. To obtain good quality extract, full ripe fruit collected between January and July were used. The fruits were kept at $-18 \pm 2{ }^{\circ} \mathrm{C}$ during the entire post-harvest and research period. 


\section{Extraction of the pigment}

Mature fruits $(2 \mathrm{~kg})$ were soaked in $2 \mathrm{~L}$ of 99.9\% methanol and $\mathrm{pH}$ was adjusted to 2.0 with concentrated hydrochloric acid (Ozela, 1996). The soaked material was left for $24 \mathrm{~h}$ at $5^{\circ} \mathrm{C}$ in a light free shelter to continue the extraction. After that, the extract was manually squeezed through a fine cloth to remove residue and then centrifugated at $2000 \mathrm{rpm}$ for $10 \mathrm{~min}$. The top layer was filtrated through Whatman paper $\mathrm{N}^{\circ} 1$ in a Buchner funnel. After filtration, chlorophyll was extracted with $100 \mathrm{~mL}$ of a 1:1 mixture of ethyl ether and petroleum ether The extract obtained was concentrated under a vacuum at $38^{\circ} \mathrm{C}$ in a rotative evaporator (Fisaton Scientific Equipments Ltd, model 802, SP, Brazil). Subsequently, freezing and drying was continued to remove water. The dried extract was weighed and stored under nitrogen in a light free shelter at $-18 \pm 2^{\circ} \mathrm{C}$ until used.

\section{Pigment stability}

Stability of crude pigment extracts. The stability of crude pigment extracts was studied at $\mathrm{pH}$ 4.0, 5.0, and 6.0. In previous trials, the dye proved to be unstable at $\mathrm{pH}$ values below 4.0. The pigment was tested in the presence and absence of light as well as in the presence and absence of heat, which was examined at 40 and $60^{\circ} \mathrm{C}$

Effect of light on pigment stability. These experiments were performed in $50 \mathrm{~mL}$ transparent glass bottles (presence of light) and $50 \mathrm{~mL}$ amber glass bottles (absence of light). Phosphate-citrate buffers were prepared at $\mathrm{pH}$ 4.0, 5.0 and 6.0. At each $\mathrm{pH}$, sufficient pigments were used to obtain the absorbance reading of 0.9 to 1.0 at $\lambda=540 \mathrm{~nm}$. To avoid fungal development, $0.2 \mathrm{~mL}$ of $5 \%$ potassium sorbate per $40 \mathrm{~mL}$ of extract was added and distributed in $50 \mathrm{~mL}$ glass bottles equipped with rubber self-sealers and aluminum seals. The glass bottles were exposed to flowing nitrogen for $10 \mathrm{sec}$. Transparent glass bottles were placed between two fluorescents light tubes of $40 \mathrm{~W}, 2,500 \mathrm{lux}$, corresponding to day light, with a distance of $10 \mathrm{~cm}$ between the fluorescent light tubes and glass bottles, which were protected from any other kind of light source at a monitored temperature of 25 $\pm 1^{\circ} \mathrm{C}$. Amber glass bottle were maintained in the light shelter at $25 \pm 1^{\circ} \mathrm{C}$. The initial reading was done after the first $2 \mathrm{~h}$ and the others in pre-determined intervals of $30 \mathrm{~min}$ each for two days. Other readings were performed at 24 $\mathrm{h}$ intervals. Maximum absorbances at $540 \mathrm{~nm}$ were determined in triplicate on a double beam spectrophotometer (Hitachi U-2001 model, Tokio Japan).

Effect of temperature on pigment stability. Amber glass bottles $(50 \mathrm{~mL})$ provided with a self-sealing rubber cap and aluminum seals were used. Extract solution $(40 \mathrm{~mL})$ was added to each flask following the same procedure mentioned above, both at 40 and $60 \pm 1^{\circ} \mathrm{C}$. Every $30 \mathrm{~min}$, samples were removed for absorbance readings at $\lambda=540 \mathrm{~nm}$.

\section{Statistical analysis}

Calculations of anthocyanin degradation parameters were obtained and absorbance data were used to build Neperian logarithm graphs from the absorbance/initial absorbance ratio (equation 1) versus time. This data was subjected to regression analysis and the angular coefficients of straight lines were obtained. Values for degradation velocity $(\mathrm{k})$ per unit time $\left(\mathrm{h}^{-1}\right)$ were obtained through the slope of straight lines. The half-life $\left(\mathrm{t}_{1 / 2}\right)$ was obtained using the first order Arrhenius equation (equation 2). The statistical parametric test was used (t for student) to verify the influence of light and temperature on the averages of degradation velocity values and the average half-life time.

$$
\begin{aligned}
& k=\ln \left[\frac{\text { absorbance }(t)}{\text { absorbance }(\text { to })}\right] \\
& \mathrm{t}_{1 / 2}=\frac{0.693}{k}
\end{aligned}
$$

\section{Results and discussion}

The effects of light, temperature, and $\mathrm{pH}$ on the stability of anthocyanins were studied by several authors, and relationships between these effects and the decomposition of the anthocyanin 
pigments has always been observed (Stringheta, 1991; Kuskoski et al., 2000).

Based on our results, $\mathrm{pH}$ had a great influence on the stability of anthocyanin pigment, both in the presence and absence of light (Figures 1 and 2, Table 1). The pigment was more stable at $\mathrm{pH} 5.0$ and 6.0 than $\mathrm{pH} 4.0$. This is a very important factor for the applicability of this dye in the food industry because most foods are found at a $\mathrm{pH}$ range greater than 4.0. According to previous results, the stability of anthocyanins depends on $\mathrm{pH}$ but, in contrast to our results, the lower the $\mathrm{pH}$ the higher the stability (Francis, 1992; Jackman and Smith, 1996).

According to Brouillard (1982), coloration

A

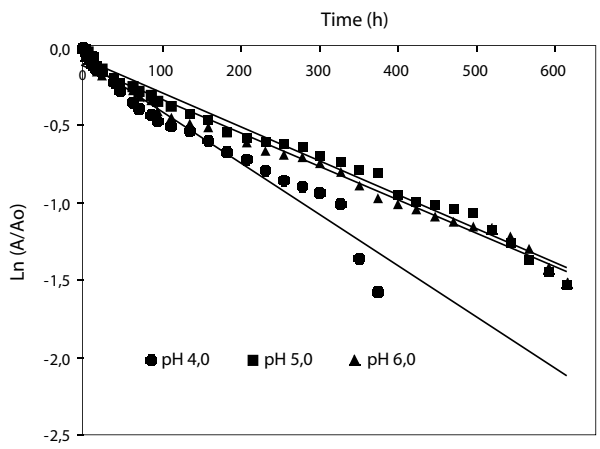

B

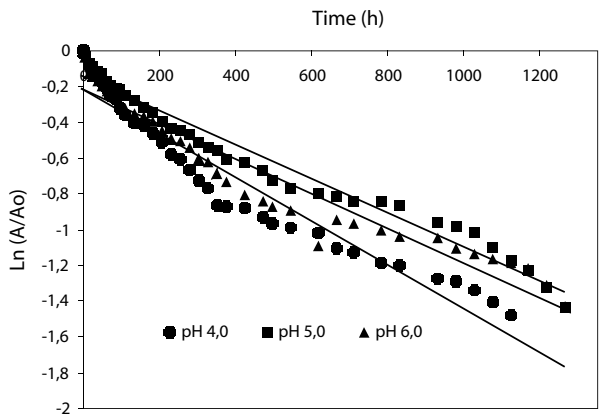

Figure 1. Degradation of spinach vine (Basella rubra) fruit extract over time in phosphate-citrate buffer systems at $\mathrm{pH} 4.0,5.0$ and 6.0 at $25 \pm 1^{\circ} \mathrm{C}$. A. In the presence of light. B.In the absence of light. $\mathrm{Ln}=$ Neperian logarithm; $\mathrm{A}=$ absorbance; Ao $=$ initial absorbance. Absorbance at $\lambda=540 \mathrm{~nm}$.

Figura 1. Degradación del extracto del fruto Basella rubra en un sistema tampón citrato-fosfato a pH 4,0; 5,0 y 6,0 en función al tiempo, en presencia o ausencia de luz a $25 \pm 1{ }^{\circ} \mathrm{C}$. A. En presencia de luz. B. En ausencia de luz. Ln = logaritmo Neperiano; $A=$ absorbancia; Ao = absorbancia inicial. Absorbancia a $\lambda=540 \mathrm{~nm}$. of anthocyanins varies with the $\mathrm{pH}$ of the environment. In aqueous environment, four types of anthocyanins exist at equilibrium i.e., flavylium cation, carbinol base, quinoidal base and chalcone. The flavylium cation form presents anthocyanins that are red in acidic environment in which they are considered to be stable (Francis, 1992). The pseudo-carbinol base and chalcone forms are colorless and prevail at neutral or slightly acidic pH (Wong, 1995). However, there are exceptions. For instance, Trandescantia pallida, in which cyaniding 3, 5, 3'- triglycosides acylated with three molecules of ferrulic acid, was demonstrated to exhibit greater stability at pH 5.5 (Shi et al., 1992).

We obtained a degradation constant $(\mathrm{k})$ of 3.3 x $10^{-3}$ with a half-life time $\left(\mathrm{t}_{1 / 2}\right)$ of $210.0 \mathrm{~h}$ in the light system at $\mathrm{pH} 4.0$ (Table 1). In contrast, in the dark system the degradation constant (k) was $3.3 \times 10^{-3}$ with a half-life time $\left(\mathrm{t}_{1 / 2}\right)$ of $210.0 \mathrm{~h}$ in the light system and at $\mathrm{pH} 4.0$ (Table 1). On the other hand, in the dark system the degradation constant (k) was $1.2 \times 10^{-3}$ and the half-life time increased to $577.5 \mathrm{~h}$. At $\mathrm{pH} 5.0$ and 6.0, samples exposed to light reached a degradation constant of $2.2 \times 10^{-3}$ a and halflife time of $315.0 \mathrm{~h}$ while, in the dark system, the degradation constant was $1.0 \times 10^{-3}$ and the half-life time was $693.0 \mathrm{~h}$ (Table 1).

A highly significant statistical difference $(\mathrm{p}=0.002)$, independent of the $\mathrm{pH}$ values, was obtained for the effect of light on half-life values. Therefore, spinach vine extract in a buffer system at $\mathrm{pH} 4.0,5.0$ and 6.0, encountered an interference of light in the degradation kinetics of the anthocyanin present in samples of the light system with average $t_{1 / 2}$ of $280 \pm 60.62 \mathrm{~h}$. In comparison, samples placed in the dark had $\mathrm{at}_{1 / 2}$ equal to $654.5 \pm 66.6 \mathrm{~h}$.

In comparison to results previously reported by Silva (1996) with Solanum americanum Mil ("Maria Pretinha") at $\mathrm{pH} 4.0$, both in the presence or absence of light $\left(\mathrm{t}_{1 / 2} 114.72 \mathrm{~h}\right.$ and $291.84 \mathrm{~h}$, respectively), results obtained in this study with spinach vine were superior under the same testing conditions. Under these conditions and this pigment had good stability constituting a promising pigment source for natural food coloring. 
Table 1. Degradation constant $\mathrm{k}\left(\mathrm{h}^{-1}\right)$ and half-life $\left(\mathrm{t}_{1 / 2}\right)$ obtained over time for phosphate-citrate buffers systems at $\mathrm{pH} 4.0,5.0$ and 6.0 in the presence and absence of light at $25 \pm 1^{\circ} \mathrm{C}$.

Cuadro 1. Valores de constantes de degradación $k\left(h^{-1}\right)$ $y$ tiempo de media vida $\left(t_{1 / 2}\right)$ en función al tiempo para sistemas buffer citrato fosfato a pH 4,0; 5,0 y 6,0 en presencia y ausencia de luz a $25 \pm 1{ }^{\circ} \mathrm{C}$.

\begin{tabular}{lcccc}
\hline System & $\mathrm{pH}$ & $\mathrm{k}, \mathrm{h}^{-1}$ & $\mathrm{R}^{2}$ & $\mathrm{t}_{1 / 2}, \mathrm{~h}$ \\
\hline Light & 4.0 & 0.0033 & 0.9565 & 210.00 \\
& 5.0 & 0.0022 & 0.9846 & 315.00 \\
& 6.0 & 0.0022 & 0.9871 & 315.00 \\
\hline Dark & 4.0 & 0.0012 & 0.9316 & 577.50 \\
& 5.0 & 0.0010 & 0.9659 & 693.00 \\
& 6.0 & 0.0010 & 0.9272 & 693.00 \\
\hline
\end{tabular}

The regression coefficients $\left(\mathrm{R}^{2}\right)$ ranged from 0.956 to 0.987 (light system) and 0.927 to 0.966 (dark system), almost a perfect fit (Table 1). These results are in accordance with the literature that reports deleterious effects of light on anthocyanin pigments (Constant, 2003).

Independent of $\mathrm{pH}$, it was evident that temperature affected the degradation of the anthocyanin pigment in the presence of light, both at 40 and $60^{\circ} \mathrm{C}$ (Figure 1). At $40^{\circ} \mathrm{C}$, the most stable system was at $\mathrm{pH} 5.0$ with a halflife of $7.46 \mathrm{~h}$, followed by $\mathrm{pH} 6.0$ with a halflife of $7.18 \mathrm{~h}$. At $60^{\circ} \mathrm{C}$, the most stable system was at $\mathrm{pH} 6.0$ with a half-life of $2.7 \mathrm{~h}$ followed by $\mathrm{pH} 5.0$ with a half-life of $2.5 \mathrm{~h}$.

Table 2. Degradation constant $\mathrm{k}\left(\mathrm{h}^{-1}\right)$ and half-life $\left(\mathrm{t}_{1 / 2}\right)$ obtained with time for phosphate-citrate buffer systems at $\mathrm{pH} 4.0,5.0$ and 6.0 in the presence of light at 40 and $60^{\circ} \mathrm{C}$. Cuadro 2. Valores de constantes de degradación $k\left(h^{-1}\right)$ y tiempo de media vida $\left(t_{1 / 2}\right)$ en función al tiempo para sistemas buffer citratolfosfato a pH 4,0; 5,0 y 6,0 en presencia de luz a temperaturas de 40 y $60^{\circ} \mathrm{C}$.

\begin{tabular}{lcccc}
\hline Temperature, ${ }^{\circ} \mathrm{C}$ & $\mathrm{pH}$ & $\mathrm{k}, \mathrm{h}^{-1}$ & $\mathrm{R}^{2}$ & $\mathrm{t}_{1 / 2}, \mathrm{~h}$ \\
\hline \multirow{4}{*}{40} & 4.0 & 0.1152 & 0.9684 & 6.01 \\
& 5.0 & 0.0928 & 0.9389 & 7.46 \\
& 6.0 & 0.0964 & 0.9758 & 7.18 \\
\hline \multirow{3}{*}{60} & 4.0 & 0.3324 & 0.9645 & 2.08 \\
& 5.0 & 0.2766 & 0.9445 & 2.50 \\
& 6.0 & 0.2559 & 0.9527 & 2.70 \\
\hline
\end{tabular}

Degradation velocity constants (k) of anthocyanins in the presence of light at $40^{\circ} \mathrm{C}$ were $1.15 \times 10^{-1}, 9.28 \times 10^{-2}$ and $9.64 \times 10^{-2}$ at $\mathrm{pH} 4.0,5.0$ and 6.0, respectively (Table 2). As temperature increased to $60^{\circ} \mathrm{C}$, value of $\mathrm{k}$ increased to $3.32 \times 10^{-1}, 2.76 \times 10^{-1}$ and 2.55 $\mathrm{x} 10^{-1}$, at $\mathrm{pH} 4.0,5.0$ and 6.0 , respectively. Regardless of $\mathrm{pH}$ values, a highly significant statistical difference $(p=0.007)$ was obtained. Therefore, a temperature of $60^{\circ} \mathrm{C}$ significantly affected the stability of anthocyanins with a mean $t_{1 / 2}$ of $2.42 \pm 0.31 \mathrm{~h}$ when compared to $40^{\circ} \mathrm{C}$, with a mean $\mathrm{t}_{1 / 2}$ of $6.88 \pm 0.76 \mathrm{~h}$.

In conclusion, the pigment extracted from the fruits of spinach vine (B. rubra) was more stable at $\mathrm{pH} 5$ and $\mathrm{pH}$ 6. Increases in temperature and the presence of light affected the stability of this pigment. Results demonstrate that this pigment exhibits good stability and could be applied to foods as a natural food color.

\section{Resumen}

En este trabajo se estudió la influencia de la luz, temperatura y $\mathrm{pH}$ sobre la estabilidad de las antocianinas presentes en el extracto de frutos de espinaca blanca, "Bertalha", (Bassella rubra L.). La extracción del colorante se realizó con metanol al 99,9\%, pH 2.0. La estabilidad del extracto antociánico se estimó por la absorbancia máxima a $\lambda=540 \mathrm{~nm}$ y en función al tiempo. Con estos valores se determinó las constantes de velocidad de reacción (k) y la vida media $\left(\mathrm{t}_{1 / 2}\right)$ en presencia y ausencia de la luz a pH 4,0; 5,0, y 6,0 tanto a 40 como a $60^{\circ} \mathrm{C}$. Los resultados indicaron que independientemente de los valores de $\mathrm{pH}$, la luz afectó la estabilidad el extracto de espinaca blanca, en la cinética de degradación de la antocianina, presentando mayor vida media para las muestras almacenadas en ambiente oscuro $(654,5 \pm 66,6 \mathrm{~h})$ y menor vida media para las muestras almacenadas en presencia de luz $(280 \pm 60,62 \mathrm{~h})$. Por otro lado, la temperatura ejerció una gran influencia en la degradación de antocianinas, alcanzando vidas medias de $280 \pm 60,62 ; 6,88 \pm 0,76$ y $2,42 \pm$ $0,31 \mathrm{~h}$ a 25 (temperatura ambiental), 40 y $60{ }^{\circ} \mathrm{C}$, respectivamente. En relación al $\mathrm{pH}$ el extracto de espinaca blanca fue más estable a $\mathrm{pH} 5,0$ y $\mathrm{pH} 6,0$ que $\mathrm{pH} 4,0$, tanto en presencia o ausencia de luz. Esto diferencia esta antocianina de otras 
que son más estables a pH más bajos. Por lo tanto, el extracto de espinaca blanca puede ser aplicado como colorante natural para alimentos.

Palabras clave: Antocianinas, Basella, Bertalha, colorante natural, espinaca blanca.

\section{References}

Adams, J.B. 1973. Colour stability of read fruit. Food Manufacture 4:19-20.

Brouillard, R. 1982. Chemical structure of anthocyanins. p.1-40. In: P. Markakls (ed.) Anthocyanins as Food Colors. Academic Press, New York, USA.

Carvalho, P.R. 1992. Potencialidade dos conservantes naturais. Revista Brasileira de Corantes Naturais 4:244-245.

Constant, P.B.L. 2003. Extração. Caracterização e aplicação de antocianinas de açaí (Euterpe oleracea M.). Tese Doutorado em Ciência e Tecnologia de Alimentos de Alimentos. Departamento de Tecnologia de Alimentos. Universidade Federal de Viçosa. Viçosa, Brasil. $183 \mathrm{pp}$.

Delgado-Vargas, F.; A.R. Jiménez, and O. ParedesLópez. 2000. Natural pigments: Carotenoids, anthocyanins, and betalains. Characteristics, biosynthesis, processing, and stability. Critical Reviews in Food Science and Nutrition. 40:173289.

Francis, F.J. 1992. A new group of food colorants. Trends in Food Science and Technology. Cambridge 3:27-30.

Hidrazina, G. 1982. Anthocyanins. Pages 135-188. In: J.B Harborne, and T. Mabry (eds.). The Flavonoids, Advances en Research. ChapmallHall, NY, USA.

Jackman, R.L., and J.L. Smith. 1996. Anthocyanins and betalains. Pages 244-296 In: G.A.F. Hendry, and J.D. Houghton (eds.). Natural Food Colorants. Blackie Academic, London, UK.

Kuskoski, E.M., P.T. Marques, and R. Fett. 2000.
Estudo comparativo da estabilidade das antocianinas do baguaçu, jambolão e da uva. Revista Brasileira de Corante Natural (Brasil) 4:73-76.

Lee, H.S., and K. Hong, 1992. Review chromatographic: Analysis of anthocyanins. Journal of Chromatographic 624:221-234.

Mazza, G. 1995. Anthocyanins in grape and grape product. Critical Review in Food Science and Nutrition 35:341-371.

Ozela, E.F. 1996. Extração e identificação da estrutura de um pigmento de fruto de Bertalha (Basella rubra L.). Dissertação Mestrado em Ciência e Tecnologia de Alimentos de Alimentos. Universidade Federal de Viçosa. Viçosa, MG, Brasil. 56 pp.

Ozela, E. F. 2004. Caracterização de flavonóides e estabilidade de pigmentos de frutos de Bertalha (Basella rubra, L.).Tese Doutorado em Ciência e Tecnologia de Alimentos.Universidade Federal de Viçosa. Viçosa, MG, Brasil. 71 pp.

Ramos, L.A, K.O. Lupetti, E.T. Carvalho, and O. Fatibello-Filho. 2000. Utilização do extrato bruto de frutos de Solanum nigrum L. no ensino de química. Ecllética Química. (Brasil) 25:110-120.

Shi, Z., M. Lin, and F.J. Francis. 1992. Stability of anthocyanins from Tradescantia pallida. Journal of Food Science 57:758-760.

Silva, S.R. 1996. Extração e estabilidade de pigmentos antociânicos de frutos de MariaPretinha (Solanum americanum. Mill.). Dissertação Mestrado em Ciência e Tecnologia de Alimentos. Universidade Federal de Viçosa. Viçosa, Brasil 76 pp.

Stringheta, P.C 1991. Identificação da estrutura e estudo da estabilidade das antocianinas extraídas da inflorescência de capim gordura (Mellinis minutiflora. Pal de Beauv), Campinas: Unicamp. Tese Doutorado em Ciência e Tecnologia de Alimentos. Faculdade de Engenharia de Alimentos, Universidade de Campinas., SP- Brasil, 138 pp.

Wong, D.W. 1995. Química de los alimentos: Mecanismos y Teoría. Editora Acribia Zaragoza, España, 380 pp. 